\title{
SZILÁGYI JÁNOS GYÖRGY
}

\section{A CUMAEI ARCHAIKUS HÉRA-SZENTÉLY}

A bonni Akademisches Kunstmuseum antik vázatöredékei közt, amelyeket a múzeum igazgatójának, Wilfried Geominynek szívessége folytán tanulmányozhattam, legalább két olyan cumaei lelóhelyú darab van, amely kétségtelenül korinthosi váza etruszk utánzatához tartozott. Az egyik (leltári száma 1615,99; m.: 9 cm; sz.: $14,5 \mathrm{~cm}$ ) egy figurális díszítésú edény maradványa; külsô oldalának díszítéséből egy fríz töredéke vehetô ki, jobbra nézô vízimadárral és egy nagy rozettával (1. kép). Minthogy belső oldala festetlen, zárt edényhez, magassága alapján alighanem oszlopkratérhoz tartozott. A másik darab (leltári száma 374,13; m.: 3,7 cm) lapos aljú, ún. Kolumbus-alabastron alsó részének töredéke; az etruszk edényforma leggyakoribb díszítéstípusa a Korinthosból átvett sziluett-fríz, amelynek állatalakjait nem tagolja bekarcolás vagy színezés. Ilyen fríz részlete a jobbra futó kutya, amelynek a töredéken csak hátsó lábai láthatók, négy barna és vörös vízszintes sáv fölött (2. kép). Egy harmadik töredék (leltári száma 1615,122; m.: 6,2 cm) alighanem egy alabastron része volt; csak a váza középső, barna sávokkal díszített részének mintegy negyede maradt meg, fölöttük két vízszintes barázdával (3. kép). Sárgásbarna agyagszíne alapján ez is etruszko-korinthosi múhelyben készülhetett, de a formának, legalábbis amennyi látható belőle, nincs meggyőzô párhuzama, és a meghatározás csak feltételes.

Etruszk múhelyben készült darabok megjelenése Cumaeban önmagában nem meglepő; első példáik már a 8. század végének sírjaiban feltúnnek. A 7. század végétől Campania jelentôs része etruszk politikai és kulturális hatás alatt állt. Ekkortól az etruszk kerámia legjellegzetesebb típusa, a bucchero-áru is elterjedt, majd rövidesen helyi utánzókra talált Campaniában, ahogy ezt a cumaei leletek is tanúsítják. Arra, hogy Cumaeba az etruszko-korinthosi kerámia is eljutott, először Payne (NC, 208), majd George Vallet utalt az Emil Stevens által 1878-1899 közt folytatott ásatások Gàbricitól publikált anyagának elemzése során. ${ }^{1}$ Ezek az egyszerú geometrikus mo-

${ }^{1}$ G. Vallet: Rhégion et Zancle. Paris 1958. 154. és 4. j. A nála említett, E. Gàbrici munkájában (MonAnt 22, 1913) reprodukált vázák közül csak a következők etruszko-korinthosiak: tav. 54,4; 55,1-2, 4-7; 71,5. Biztosan korinthosi tav. 55,3 és 543 (nem 143!), fig. 194. Legutóbb V. Bellelli: StEtr 64 (1998, megj. 2001) 11-13 és 26-28, további cumaei, nem figurális díszítésú vázákat közölt. 


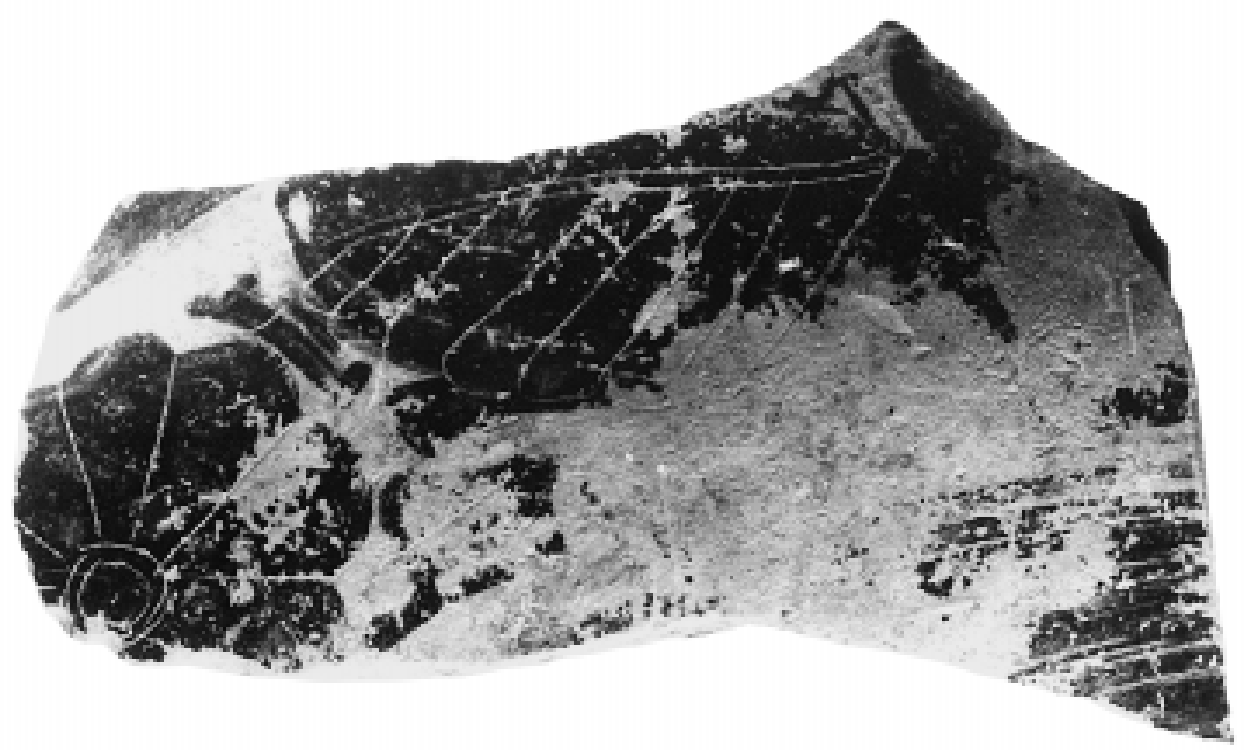

1. kép. Etruszko-korinthosi váza töredéke Cumaeból. Bonn, Akademisches Kunstmuseum (múzeumi fotó)
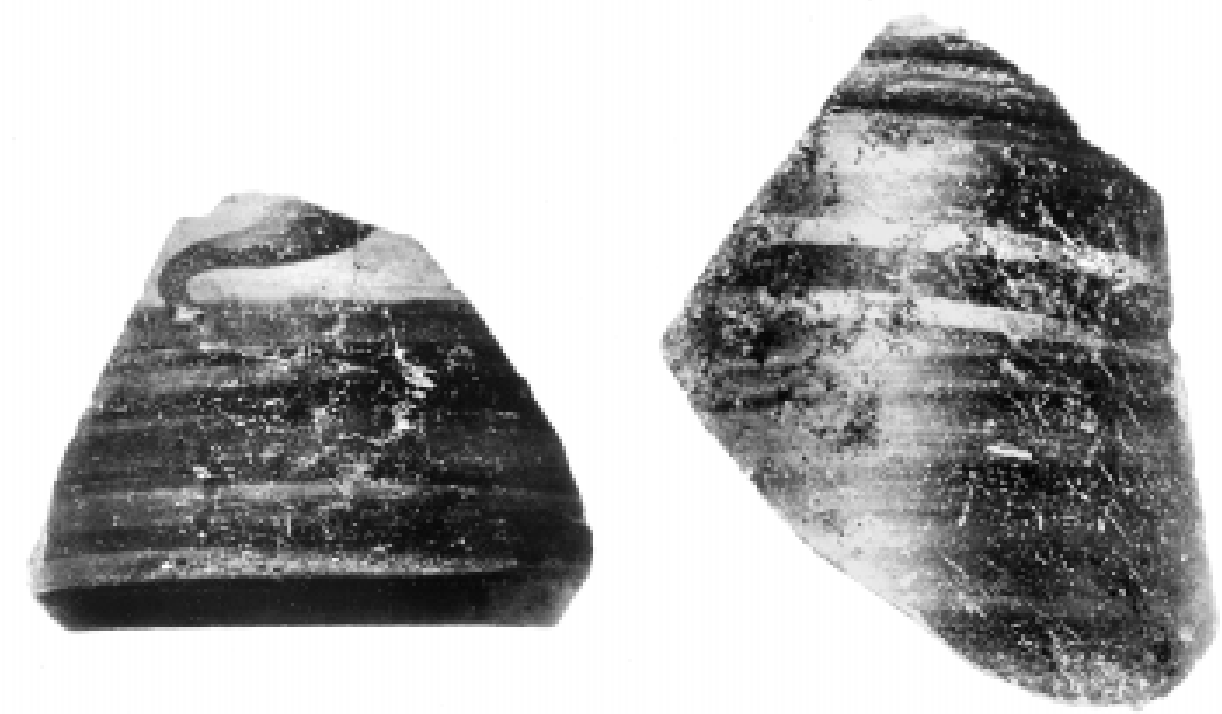

2-3. kép. Két etruszko-korinthosi váza töredéke Cumaeból. Bonn, Akademisches Kunstmuseum (múzeumi fotó) 
tívumokkal vagy csak sávokkal díszített darabok azonban mai tudásunk szerint nem alkalmasak arra, hogy Dél-Etrurián belül készítési helyüket meghatározhassuk vagy keltezésüket szúkebb időhatárok között megadhassuk. Ugyanez áll a sziluett-technikával festett, egy vagy több állat- (többnyire futó kutya-) frízzel díszített etruszkokorinthosi vázák egész csoportjára. ${ }^{2}$ Teljesen más azonban a helyzet a figurális díszítésú töredékkel. Ezen a mesterkéz minden nagyobb nehézség nélkül azonosítható: az 580-560 közt Vulciban múködött Rosoni-festô munkája. Ez két szempontból is figyelmet érdemel. Egyrészt ennek a rendkívül termékeny mesternek jelenleg azonosított mintegy 270 vázája közül csaknem 150-nek ismert a lelőhelye, és ezeknek tanusága szerint csak négy munkája került elő a Tiberistől délre vagy Itálián kívül: egy gömbaryballos Marseille-ben, két bizonytalan formájú töredék Satricumban, és ezekhez járul negyedikként a cumaei cserép, amely kitágítja múveinek elterjedési körét. ${ }^{3}$ Másrészt a Rosoni-festő vázája az elsô tárgyi bizonyítéka Vulci és Cumae érintkezésének - ha nem is feltétlenül közvetlen kapcsolatának — az orientalizáló korszakban.

Lehetségesnek látszik továbbá a három bonni etruszk vázatöredék lelőhelyének Cumaen belül közelebbi megjelölése és ezáltal az eredetivel nem feltétlenül azonos legkésóbbi ókori funkciójuk meghatározása is. Az Akademisches Kunstmuseum leltárkönyvében Georg Loeschcke kézírásával a 373-377. számok mellett a következő megjegyzés olvasható: „Geschenk von Professor Dr. E. aus'm Weerth aus Kessenich”. Valamennyi tétel lelőhelyeként Cumae van feltüntetve, és ezt a 373., 374. és 376. tételnél még kiegészíti az utalás arra, hogy az egykori Wittgensteingyújteményből származnak. A leltárkönyv további lapjain 98 alszámmal ellátott „Cumaeból származó cserép” („Scherben aus Cumae”) van felsorolva a 374. tétel, vagyis a Wittgenstein-gyújteményből származó anyag részletezéseként. Ezenkívül az 1615. gyújtôszámon további 123 „Scherben aus Cumae” van leírva, amelyek nyilvánvalóan a fenti töredékekkel együtt és azonos helyről kerültek a múzeumba. Összesen tehát 221 töredékról van szó; túlnyomórészt korinthosi vázák maradványai, de mintegy 50 darab az importált korinthosi vázák itáliai utánzatai közé tartozott, amelyek a három etruszko-korinthosi darabot kivéve helyi, C. W. Neeft véleménye szerint legalábbis részben ischiai múhelyben készültek. ${ }^{4}$

A bonni töredékeknek és a Wittgenstein-gyújtemény jónéhány további darabjának történetét idóben visszafelé haladva egészen feltárásukig tudjuk rekonstruálni. Egykori tulajdonosuk, Emil Prinz zu Sayn-Wittgenstein-Berleburg (1824-1878), ${ }^{5}$ a

${ }^{2}$ A csoport egyetlen részletesebb, de már eleve csak Tarquinia anyagára korlátozott vizsgálata a keltezésre és lokalizálásra vonatkozólag nem hozott lényeges eredményt ( $V$. Bellelli: in: Miscellanea etrusco-italica II. Roma 1997. 7 skk., kül. 36-38).

${ }^{3}$ A festôrôl a korábbi irodalommal Szilágyi $J$. Gy.: Ceramica etrusco-corinzia figurata II. Firenze 1998. 334 skk.; a Marseille-ben talált töredék uo. 349, n. 247; a satricumi töredékek uo. 346, n. 204 és 349, n. 261; a fent tárgyalt cumaei töredék uo. 335, n. 9bis és $370,246 . j$.

${ }^{4}$ A bonni töredékekről C. W. Neeft, in: Atti Taranto 1994 (1997) 377 sk., kül. 12. j. és a mintegy 160 importált korinthosi vázatöredék szisztematikus feldolgozása: fig. $14 \mathrm{a}-\mathrm{b}$.

${ }^{5}$ L. róla: Allgemeine Deutsche Biographie 43 (1898, Neudruck 1971), 619. 
porosz hadseregból fiatalon kilépve az orosz cári hadsereg tábornoka lett; 1856-ban diplomáciai misszióban Párizsba ment, ott megismerkedett egy Cantacuzino hercegnővel, akivel Wiesbadenben rövidesen összeházasodtak. Felesége egészségi állapota miatt 1857-1860 közt többnyire Nápolyban éltek, és a végnapjait éló Bourbonkirályság fővárosában a társadalom legfelső rétegének életébe kapcsolódtak be. A herceg közeli barátságba került Lipóttal, Siracusa grófjával, a Két Szicília Királysága utolsó Bourbon királyának, II. Ferencnek a testvérével, és részt vett annak 1852 óta folytatott cumaei ásatásain, ${ }^{6}$ amelyeknek leletei ma a nápolyi Museo Archeologico Nazionale ún. Cumaei Gyújteményének (Raccolta Cumana) mindeddig csak kis részben publikált anyagát képezik. Késôbb egy Nápolyból 1860. január 13-án szüleinek írt levelében Wittgenstein herceg arról számolt be, hogy unalomúzésból az elmúlt héten maga is ásatásokat folytatott Cumaeban. ${ }^{7}$ (Zárójelben érdemes emlékeztetni rá: négy hónap múlva Garibaldi önkénteseivel partra szállt Szicíliában, és októberre összeomlott a Két Szicília Bourbon királysága.)

Az ásatásról az egyetlen hiteles írott tudósítás Giulio Minervininek, a cumaei régiségek érdemes kutatójának és az ásatásokról rendszeresen tudósító régésznek rövid beszámolója. Ebben a hely közelebbi megjelölése nélkül röviden ismertette az elókerült leletek néhány érdekesebb darabját, majd három kiválasztott vázát tárgyalt részletesen, rajzos reprodukcióval illusztrálva. Csak mintegy mellékesen jegyezte meg, hogy az ásatáson talált vázák és töredékek ,most E. de Sayn Wittgenstein herceg birtokában vannak". ${ }^{8}$ Nem zárható ki annak a lehetôsége, hogy a herceg több kisebb ásatást is szervezett. Levelezésének halála után egy évtizeddel Párizsban megjelent kiadása ugyanis nem teljes, elsősorban a politikai szempontból érdekes részletekre terjed ki; az ásatásokról szóló fent említett tudósítás első mondata után kipontozott rész következik, alighanem csak egyike a hasonló tartalmú kihagyott részeknek, az eredeti teljes kézirat hollétéról azonban a család ma éló tagjai sem tudtak felvilágosítást adni. Mindenesetre utalni kell arra, hogy bár a herceg levele és Minervini tudósítása nagyjából egyidejú, a levélben felsorolt leletek nem azonosak azokkal, amelyeket az olasz régész leírt: az utóbbi csak vázákról tesz említést, a herceg játékkockákat és egy bronz tükröt emel ki a leletek között, másfelól Minervini antik épületromok mellett, Wittgenstein sírokban előkerült tárgyakról beszél. Egyikük sem törekszik teljességre a talált tárgyak felsorolásában, és a herceg régészeti ismeretei minden jel szerint igen szerények lehettek, de a két beszámoló közti eltéréseket számon kell tartani. Az azonban bizonyítható, hogy a gyújteménynek az aláb-

${ }^{6}$ „Notre seule recréation consiste à faire des fouilles presque journellement”, írja szüleinek Sorrentóból 1858. június 17-én kelt levelében (Souvenirs et correspondance du prince Émile de SaynWittgenstein-Berlebourg I. Paris 1888. 382). Siracusa grófjának ásatásairól legutóbb A. de Filippis, in: La Magna Grecia nelle collezioni del Museo Archeologico di Napoli. Napoli 1996. 215-218 (a korábbi irodalommal).

7 ,J'ai fait cette semaine quelques fouilles à Cumes”: i. h. 405.

8 BullArchNap N. S. 8 (1860) 25 skk. és tav. 5. 
biakban fố szerepet játszó archaikus kerámiaanyaga legalábbis túlnyomórészt abból az ásatásból származik, amelyrôl Minervini tudósít.

Kevés adat maradt fenn a gyújtemény sorsáról az ásatást vagy ásatásokat követő években. A gyújteményról soha nem készült katalógus vagy leírás, és az ásatásokról később sem jelent meg semmilyen tudósítás. Tudjuk, hogy a herceg, aki nyilván sietve elhagyta az immár egységes Itáliához tartozó Nápolyt, 1863-ban visszatért Oroszországba, gyújteménye azonban Wiesbadenben maradt. Ott volt módjában Otto Jahnnak, akkor már bonni professzornak 1865-ben megtekinteni, sôt a herceg azt is megengedte neki, hogy a gyújtemény egyik athéni vörösalakos pelikéjét publikálja. ${ }^{9}$ Cikkében Jahn a gyújtemény eredetére is kitért, és utalt arra, hogy annak „jelentős részét részben nápolyi múkereskedelemből, részben saját ásatásai során” szerezte tulajdonosa. Ez a megjegyzés alátámasztható, illetve kiegészíthetô néhány nyomtatásban közölt vagy kéziratos dokumentummal, amelyek nagyrészt a gyújtemény egy részének Drezdába kerülését kísérték; a legértékesebb közülük a jelenleg a drezdai Staatliche Kunstsammlungen irattárában ôrzött kéziratos jegyzék a megszerzendő tárgyakról, amelynek alighanem a herceg által fogalmazott bevezetése részletes, bár elsősorban a vásárlás tárgyát képező darabokra korlátozott felvilágosítást ad vázagyújtésének fő forrásairól.$^{10} \mathrm{~A}$ jelenleg fellelhető adatok alapján a gyújtemény a következő fóbb részekből állt: 1 . A cumaei ásatások anyaga (túlnyomórészt 7-6. századi korinthosi vagy azt utánzó vázák és töredékek, valamint archaikus épületdíszítő terrakották töredékei); 2. Mintegy 80 váza Vincenzo Foglia egykori nolai gyújteményéből (többnyire 5. századi athéni vörösalakos vázák campaniai és egyéb dél-itáliai lelőhelyekrő́l, többek közt Nolából, a Sorrentói-félszigeten levő S. Agata sui Due Golfiból, Capuából, a Basilicatából, továbbá az apuliai Ruvóból és Canosából); 3. Nápolyi múkereskedelemben vásárolt darabok (például Herculaneumból és Pompeiból származó leletek, köztük nagyobb méretú márvány és stukkó szobrok is); 4. A Krím-félszigeten szerzett régiségek (köztük borostyánkő gyöngyök); 5. Római provinciális lelettárgyak (fóleg bronzok).

C. Friederichs a berlini múzeum bronzainak 1871-ben kiadott katalógusában még utalt a gyújteményben ôrzött bronz fibulákra. ${ }^{11}$ Két évvel később azonban a gyújtemény egyelőre ismeretlen okokból feloszlott. Minden jel arra mutat, hogy az értékesítésben Ernst aus'm Weerth bonni régészé volt a fő szerep. ${ }^{12}$ Fennmaradt a

${ }^{9}$ ArchZeit 23 (1865) 17 és Taf. 194; Beazley: ARV², 665,4.

${ }^{10}$ A fentiekre vonatkozó felvilágosításokért Dr. Kordelia Knollnak, a drezdai Staatliche Kunstsammlungen tudományos munkatársának tartozom köszönettel. A két legfontosabb dokumentum a Dresdner Journal 1873. évi 192. számának melléklete és a megvásárolt vázák kéziratos jegyzéke az élén álló megjegyzésekkel, jelenleg a Staatliche Kunstsammlungen archívumában.

${ }^{11}$ C. Friederichs: Geräte und Bronzen im Alten Museum. Berlin 1871. 318; vö. F. v. Duhn: BullInst $1878,156,1 . \mathrm{j}$.

12 Életéről (1829-1909) és tevékenységéről P. Clemen: Kunstchronik N. F. 20 (1909) 361-363; R. Fuchs: in: Rheinisches Landesmuseum Bonn, 150 Jahre Sammlungen 1820—1970. Düsseldorf 1971. 99_ 117. 
hercegnek egy 1873. május 8-án kelt, hozzá intézett levele, amelyben meghívja gyújteménye megtekintésére. ${ }^{13}$ A gyújtemény ekkor Bécsben volt, az ebben az évben rendezett világkiállítás színhelyén. A kiállításnak - Párizs után másodszor — régészeti, ún. amatốr részlege is volt, amely adminisztratív problémák miatt csak megkésve, a nyár közepén nyílt meg. ${ }^{14}$ Aus'm Weerth levelezésének tanúsága szerint valamikor június 3-a és július 30-a közt Bécsbe látogatott, és ugyanez év „őszén” ahogy közelebbi dátum nélkül írja - megvásárolta a Wittgenstein-gyújteményt. Fó célja aligha teljesen ôszinte levele szerint az volt, hogy a bonni Verein von Altertumsfreunden im Rheinlande számára Rajna-vidéki régiségeket szerezzen. ${ }^{15} \mathrm{~A}$ vétel részletei nem ismeretesek, bizonyos azonban, hogy a gyújtemény anyaga nem szerepel a világkiállítás régészeti anyagának hivatalos jegyzékében; mint Henszlmann Imre, a kiállítás magyar anyagának szakbiztosa beszámolójában megjegyezte, a vázafestészet teljesen hiányzott a régészeti tárgyak közül. ${ }^{16} \mathrm{~A}$ rendezvény mindenesetre kiváló alkalmat nyújtott aus'm Weerth-nek — aki ezt nyilván jól felmérte -, hogy kapcsolatba lépjen antik tárgyak vásárlásában érdekelt intézményekkel és személyekkel. Az ő közvetítésével vásárolta meg Hermann Hettner, a drezdai Skulpturensammlung (akkori nevén Szász Királyi Antik-Kabinett) igazgatója a múzeum számára a Wittgenstein-gyújtemény 112 vázáját, és ugyanekkor szerzett a fiatalon Bécsben tanuló Pulszky Károly atyai barátjától, Johannes Overbeck lipcsei professzortól támogatva mintegy hetven antik tárgyat ugyancsak a Wittgenstein-gyújteményból az akkor létesülő, önálló épülettel még nem rendelkező Iparmúvészeti Múzeum számára, alighanem szintén aus'm Weerth közvetítésével, bár neve nem fordul eló a fennmaradt iratokban. A Henszlmann Imre vezette magyar vásárló bizottság fố célja minél változatosabb, az „iparmúvészetek” minél több múfaját képviselő anyag megszerzése volt, a hazai kézmúvesség különböző ágainak ösztönzésére. Ez magyarázza, hogy a vásárolt, ma a Szépmúvészeti Múzeum antik gyújteményében őrzött tárgyak közt Cumaeban talált korinthosi és korinthosit utánzó helyi készítésú vázák sorozata mellett athéni vörösalakos és feketemázas, főként 5. századi és nyilván a Fogliagyújteményből kikerült vázák jelentős anyaga szerepel Cumae, Nola, Capua és S. Agata sui Due Golfi lelőhelyekkel, továbbá Cumaeból származó görög, színes formába öntött üvegpaszta és talán provinciális eredetú római fújt üvegedények, görög

${ }^{13}$ A levél szövegét és a következőkben említendő dokumentumok jelentős részét Gabriele John asszony bocsátotta rendelkezésemre, aki jelenleg aus'm Weerth professzor életrajzán dolgozik. Hálás köszönettel tartozom neki önzetlen segítőkészségéért.

${ }^{14}$ Részletesen tudósít erről Henszlmann I.: A bécsi 1873. évi világ-tárlatnak magyarországi kedvelóinek (sic) régészeti osztálya (Magyarország Régészeti Emlékei, II. kötet, II. rész). Budapest 1875/6. $4-5$.

${ }^{15}$ Levél Heinrich Brunnhoz, 1874.3.16. Bayerische Staatsbibliothek, Handschriften- und Inkunabelabteilung, Brunniana III/aus'm Weerth, Ernst, Bl.2. A levél másolatáért a Bayerische Staatsbibliothek Igazgatóságának fejezem ki ehelyütt is köszönetemet.

${ }^{16}$ Henszlmann: i. m., 45. 
és római aranyékszerek, mellettük pedig színes festésú archaikus épületburkoló terrakotta lapok töredékei. ${ }^{17}$

A Wittgenstein-gyújtemény jelentôs része azonban a világkiállítás után is aus'm Weerth birtokában maradt. Ez világosan kitûnik 1874 márciusában Heinrich Brunnhoz írt, fentebb már említett leveléből, amelyben a gyújtemény tárgyainak egy sorát, közte a Minervini cikkében illusztrációval kísérve tárgyalt két korinthosi vázát ajánl fel megvételre a müncheni múzeumnak azzal, hogy számára nem a vételár a fontos, hanem az, hogy a darabok méltó helyre kerüljenek. Nem ismerjük az alighanem személyes okát annak, hogy a berlini múzeumot eleve kizárta a szóba kerüló vásárlók közül, sem azt, hogy miért tért ki a vásárlás elől a müncheni múzeum. A döntés mindenképpen Brunntól származott, aki ekkor a klasszika archaeologia müncheni tanszékének professzora, egyszersmind a vázagyújtemény kurátora volt. Minden valószínúség szerint az ő közvetítésével szerezte meg a megmaradt tárgyak jelentős részét tekintélyes antik gyújteménye számára Emile de Meester de Ravestein belga diplomata. Aus'm Weerth egy Brunnhoz intézett levelében, amelyben korábbi ajánlatát száz ólom parittyagolyóval egészítette ki, a belga gyújtőt „közös barátjuk”-nak nevezte. ${ }^{18}$ Valóban Brunn volt Meester de Ravestein fó tanácsadója vásárlásainál, és gyújteménye első nyomtatott katalógusának írásában is tevékenyen részt vett. Később ő beszélte le arról, hogy antik tárgyait a müncheni múzeumnak adja, és így került végül a gyújtemény 1874-ben a brüsszeli Musées Royaux d'Art et d'Histoireba, amelynek a klasszikus ókor területén törzsanyagát alkotja. ${ }^{19}$ A katalógus fentebb említett, 1872-ben publikált elsô kiadásában a Wittgenstein-gyúijteménybôl származó darabok még nincsenek megemlítve. Elóször az 1882-ben kiadott Supplément-ben tûnnek fel, és a két évvel késóbb megjelent második kiadásban vannak leírva, többnyire származásuk megjelölésével. Itt szerepel a Minervini cikkében részletesen elemzett két fentebb említett korinthosi váza, ${ }^{20}$ továbbá két, ugyanezen az ásatáson elôkerült ugyancsak korinthosi edény, ${ }^{21}$ valamint 14 kisbronz szobor, egy kivétellel római, legalábbis részben provinciális múhelyből, továbbá 8 agyagedény, két aranyékszer és egy üveg töredéke, valamennyi mellett „a Wittgenstein-gyújteményböl” vagy „Cumaeból” megjegyzéssel. Ma már nem lehet pontosan megállapítani, hogy mikor történt a vásárlás 1874 és 1882, a Supplément megjelenése közti időben, de alighanem még 1874-ben, a gyújtemény elajándékozása elôtt vagy azzal összefüggés-

17 A vásárlásról az azonosítható tárgyak jegyzékével, Szilágyi J. Gy., in: Pulszky Károly in memoriam (szerk. Mravik L.). Budapest 1988. 64-69.

${ }^{18}$ A levél kelte 1874.4.13. Bayerische Staatsbibl., i. h. (fent 15. j.), Bl.3.

${ }^{19}$ Minderről legutóbb J.-Chr. Balty, in: Les Etrusques et l'Europe. Paris 1992. 366-369 (további irodalommal).

${ }^{20}$ Alabastron, ltsz. R 225: CVA Bruxelles 1, III C, pl. 2,63; D. A. Amyx: Corinthian Vase-Painting of the Archaic Period. Berkeley-Los Angeles-London 1988. 56, Typhon Painter n.1 (irodalommal). Gömbaryballos, ltsz. R 221: CVA, i. h., pl. 1,36; Amyx, i. m., 620,7 (irodalommal).

${ }_{21}$ Aryballos, ltsz. R 207: CVA, i. h., pl. 1,17 (irodalommal). — Pyxis, ltsz. R 189: CVA, i. h., pl. 1,3. 
ben, nem sokkal aus'm Weerth Brunnhoz intézett, fentebb említett második levele után. Ugyanebben az időben aus'm Weerth, akinek nyilvánvalóan anyagi érdekei fúződtek a gyújtemény értékesítéséhez, római bronzok sorozatát adta el a bonni Verein von Altertumsfreunden im Rheinlande-nak. ${ }^{22}$ Ekkortól azonban — úgy tûnik - megszakadt a gyújteménnyel kapcsolatos tevékenysége, alighanem másirányú elfoglaltsága miatt: 1875-tól 1883-ig az általa alapított bonni Provinzialmuseum, majd annak máig élő utódja, a Rheinisches Landesmuseum igazgatója volt. Hivatalából a jelek szerint erkölcsi okokból felmentve a Bonnhoz közeli Kessenichben vidéki birtokán élt, amikor 1889-ben Georg Loeschckét nevezték ki a bonni egyetem professzorává, egyszersmind az Akademisches Kunstmuseum igazgatójává. A tudományos ásatástechnika tökéletesítésétől az ikonográfiai kutatás alapelveinek kidolgozásáig a klasszika archaeológia számos területén maradandó értékú munkásságának egyik fő teljesítménye volt az antik vázatöredékek jelentőségének felismerése, aminek első komoly eredménye a mykénéi kerámiáról Furtwänglerrel közösen írt munkája lett. ${ }^{23}$ Érthetó, hogy Bonnban első feladatai közé sorolta egy mind a tanítás, mind a kutatás szempontjából fontosnak tudott antik kerámiagyújitemény szisztematikus kiépítését, a cserepeket azonos jelentőségúnek ítélve a teljes darabokkal. Így alighanem ő beszélte rá aus'm Weerth-et, hogy a Wittgenstein-gyújtemény még birtokában levő vázatöredékeit az Akademisches Kunstmuseumnak ajándékozza nem tudjuk, milyen feltételekkel, és az 1615. gyújiőzzámmal jelölt darabok esetében vásárlás is elképzelhetố. Mindenesetre szinte kizárólag görög és itáliai vázák töredékeiről volt szó, jóformán egyetlen ép darab sem került az akció során a múzeumba, jóllehet Wittgenstein antik tárgyainak egy közelebbról meg nem határozható menynyisége még Kessenichben volt. Ennek kétségtelen bizonyítéka az aus'm Weerth antik tárgyaiból 1895-ben Kölnben árverésre bocsátott anyag katalógusa, amelyben jónéhány, a Wittgenstein-gyújteményből származó tétel található eredetük feltüntetésével, köztük Kercsben szerzett borostyánkő gyöngyök és egy kakas alakú plasztikus edény, amelynek rövid leírása szerepel Minervini ásatási beszámolójában. ${ }^{24}$ Így a katalógus Előszavának az az állítása, hogy az aukción szerepló gyújtemény tulajdonosának nyugdíjazása után jött létre, legföljebb részben felel meg a valóságnak, és elsősorban a római provinciális és a koraközépkori anyagra vonatkozhat, amelyet aus'm Weerth múzeumigazgatósága idején hivatalosan nem gyújthetett. A Wittgenstein-gyújjteményből származó darabokat a megszerzésük és halála közti évtizedekben feltehetôleg a fenti nagyobb ügyleteken kívül kisebb tételekben vagy egyenként

22 BJb 55/56 (1875) 269-278. Gabriele John szíves közlése.

${ }^{23}$ G. Loeschckéról (1852-1915) W.-R. Megow, in: Archäologenbildnisse (hrsg. R. Lullies-W. Schiering). Mainz 1988. 106-107 (bő irodalommal). Tevékenységérốl a bonni múzeumban N. Himmelmann: Das Akademische Kunstmuseum der Universität Bonn. Berlin é. n. 12.

${ }^{24}$ Katalog der ... Antiken-cabinete der Herrn ... F. H. Wolff und Prof. Dr. E. aus'm Weerth in Kessenich bei Bonn. Versteigerung zu Köln durch J. M. Heberle, 1895. Nr. 483 (a borostyánkő gyöngyök) és Nr. 518 (a kakas-edény). 
is értékesített. Mindenesetre a kevéssel halála után hagyatékából rendezett árverésen számos antik tárgy szerepelt, de a több gyújtemény anyagát együttesen tartalmazó katalógusban sem az egyes tulajdonosok anyaga nincs elkülönítve, sem származási adatok nem kísérik az egyes tételeket. ${ }^{25}$ A szétszóródott gyújtemény egyes darabjai még később, jóval aus'm Weerth halála után is felbukkantak a múkereskedelemben, így egy polykleitosi ifjúalak római márvány másolatának torzója 1920-ban egy aacheni aukción, majd nemrégiben egy amerikai magángyújteményben. ${ }^{26}$ Megadott provenienciája - „Herculaneumból vagy Pompejiből” - megalapozottnak túnik: aus'm Weerth Brunnhoz intézett, fentebb említett elsố levelében említést tett a gyújtemény nehezen mozgatható, nagyméretú, Pompeiből származó darabjairól.

Mindez önmagában legföljebb gyújtemény- vagy tágabb értelemben múvelődéstörténeti érdekesség volna. A sokfelé osztódott Wittgenstein-gyújtemény igazi jelentôsége azonban, ahogy ez a legutóbbi két évtized kutatásai alapján mind világosabbá vált, régészeti forrásértékében van, elsôsorban természetesen az ásatásokból származó cumaei anyagé. Már Minerviniben felmerült a gondolat, hogy az általa kiásott kerámialeletek kapcsolatban állhattak a szomszédos épületromokkal, sốt ennél konkrétabban azt a feltevést is megkockáztatta, hogy esetleg egy Héra- vagy Zeus-templom favissa-járól lehet szó. ${ }^{27}$ Az egyetlen ókori írott forrás Héra cumaei templomáról a Hadrianus korában múködött tralleisi Phlegónnak a csodás jelenségekről írt, csak töredékeiben fennmaradt múvében idézett Sibylla-jóslat; ennek forrása nem korábbi a Kr. e. 2. századnál. ${ }^{28}$ A cumaei Héra-kultusz legkorábbi ismert dokumentuma egy még a Kr. e. 7. század vége tájára keltezhető bronzkorong, rajta Hérának a jóslatokkal való kapcsolatára utaló, részleteiben többféleképpen értelmezett felirattal egy nápolyi magángyújteményben. ${ }^{29}$ Minthogy az 1900-as évek elején felbukkant korong pontos lelóhelye ismeretlen, és a Phlegón-szövegben sincs utalás a Héra-templom lokalizálására, érthetô, hogy Minervini hipotézise sokáig szinte visszhang nélkül maradt. ${ }^{30}$ Fordulatot jelentettek azonban ezen a téren a Nazarena Valenza Mele, a nápolyi Federico II Egyetem fiatalon elhunyt professzora által mintegy negyedszázaddal ezelőtt indított kutatások. Az ô egyik érdeme az, hogy a Wittgenstein-ásatások színhelyét feltételesen az egykori „fondo Valentino”-ra, a város déli részén közvetlenül az antik városfalon kívül fekvő területre lokalizálta.

${ }^{25}$ Katalog der nachgelassenen Kunst-Sammlung des Herrn Professor Dr. Ernst aus'm Weerth, Bonn-Kessenich, und anderer. Versteigerung zu Bonn, 1909.

${ }^{26}$ C. A. Picón, in: Polykleitos, the Doryphoros, and Tradition (ed. W. G. Moon). Madison (Wisconsin) 1995. 233, fig.13.20-21 és 41 . j.

27 Minervini, i. m. (fent 8. j.), 27.

${ }^{28}$ Máig alapvető tárgyalása H. Diels: Sibyllinische Blätter. Berlin 1890.1-23; a szöveg kiadása uo., 111-115. Újabban részletesen foglalkozott a szöveggel L. Breglia Pulci Doria: Oracoli sibillini tra rituali e propaganda. Napoli 1983 (munkájához nem tudtam hozzájutni).

${ }_{29}$ M. Guarducci: BullCom 72 (1946—48, megj. 1951) 129-141 (a korábbi irodalommal); a keltezéséról Ua.: ArchCl 16 (1964) 136-138; az értelmezéshez G. Pugliese Carratelli, in: Atti Taranto 1978. Taranto 1984. 222-224.

${ }^{30}$ Kivétel Gàbrici, aki Minervini nyomán Héra-templomra gondolt: i. m. (fent 1. j.), 43, 1. j. 
Ennek igazolására utalt Stevensnek a nápolyi Főfelügyelőség archívumában talált kiadatlan jegyzetére, amelyben a Héra-templomot az általa talált leletek alapján ugyanide, a városfal külsố délnyugati szögletére helyezte. Hivatkozott továbbá a Minervini által tárgyalt harmadik vázatöredékre, rajta Hérának szóló dedikációval, amelyet az olasz régész a váza reprodukálása nélkül, de pontos apográffal közölt, valamint a nápolyi múzeum raktárában őrzött és korábban figyelemre is alig méltatott, ${ }^{31}$ először általa közölt öt 6-5. századi feketemázas vázatöredékre Cumaeból, rajtuk bekarcolt Héra-dedikációval. ${ }^{32}$ Nem kerülhette el a figyelmét, hogy ezek egyike sem döntő bizonyíték. Stevens az említett jegyzetet kihagyta publikációjából, és nem jelezte, hogy közelebbrôl milyen leletekre alapozza véleményét; a Minerviniféle töredékre való hivatkozás önmagában circulus vitiosusba vezetett, hiszen épp a töredék lelőhelyének azonosítása volt a kérdés; az öt Héra-dedikációs váza közelebbi lelőhelye Cumaen belül ismeretlen, így csak a Héra-kultusz korai elterjedését igazolták a városban. Nyilván mindezeknek a mérlegelése révén jutott arra a meggyőződésre, hogy végleges eredményt csak új, tudományos módszerrel folytatott ásatások hozhatnak. Ezért ösztönözte tanítványait, hogy a helyi Gruppo Archeologico nyomában kutatásokat végezzenek a „fondo Valentino” területén.

Az ásatások, amelyeknek jelentése már csak az emlékének szentelt kötetben került közlésre, ha nem is végleges, de fontos és továbbmutató eredmények sorát hozták. ${ }^{33}$ Egyszersmind egyre nyilvánvalóbbá vált a jelentősége a Wittgensteingyújtemény szétszórt részei együttes áttekintésének. Valenza Mele egyik tanítványa, Carlo Rescigno vette észre, hogy a herceg gyújteményéból származó, egyik épületdíszítő terrakotta (ún. strigilis-sima) töredék, amelyet Pulszky Károly Bécsben vásárolt, és jelenleg a Szépmúvészeti Múzeum antik gyújteményében van, szorosan öszszefügg a „fondo Valentino” új ásatásain előkerült töredékek egyikével ${ }^{34}$ (4-5. kép). Ez további bizonyítéka annak, hogy a Minervininél említett romok kultuszépület maradványai voltak, és egyúttal kétségtelenné teszi, hogy az ásatás színhelye azonos a „fondo Valentino”-val. Másfelől sikerült a bonni Akademisches Kunstmuseum cserép-gyújteményének a 374. számon összefoglalt, tehát a Wittgenstein-gyújteményből származó darabjai közt megtalálni a Minervini által publikált Héra-dedikációt, jelenleg az egyetlen cáfolhatatlan bizonyítékát az istennő kultuszának ezen a területen. Csaknem ugyanennyire fontos, hogy a feliratot hordó töredék azonosítása a váza Minervini leírása alapján zavart és kétkedést támasztó meghatározásának konkretizálására is lehetőséget adott: konikus testú, hosszúnyakú korinthosi oinochoé volt, a

${ }^{31}$ L. azonban M. Guarducci: Epigrafia greca I. Roma 1967. 399.

32 Legfontosabb ide vonatkozó múvei: N. Valenza Mele: MEFRA 89 (1977) 498-504 és 524; RIA 3. ser. 14/15 (1991/1992) 9-20 és figg. 7-10.

${ }^{33}$ L. La Rocca-C. Rescigno-G. Soricelli, in: Studi sulla Campania preromana (a cura di M. Cristofani-F. Zevi). Roma 1995. $51 \mathrm{skk}$. n. 78

${ }^{34}$ C. Rescigno: Tetti campani. Età arcaica. Roma 1998. 194, 216, n.77, tav. 7 és fig. 31, valamint uo. 


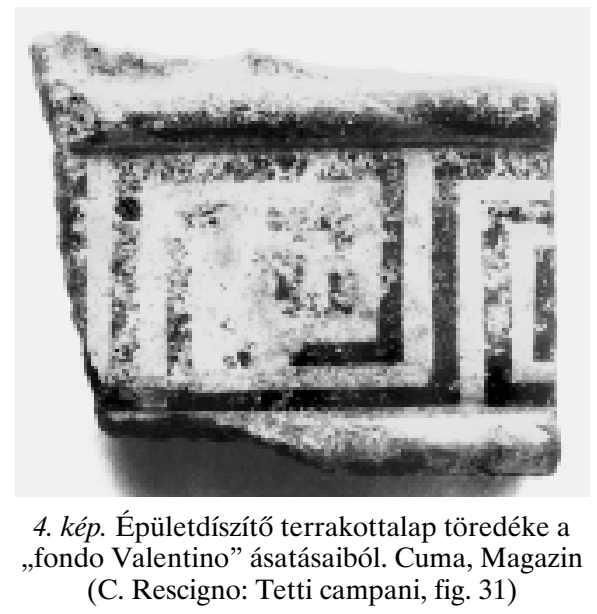

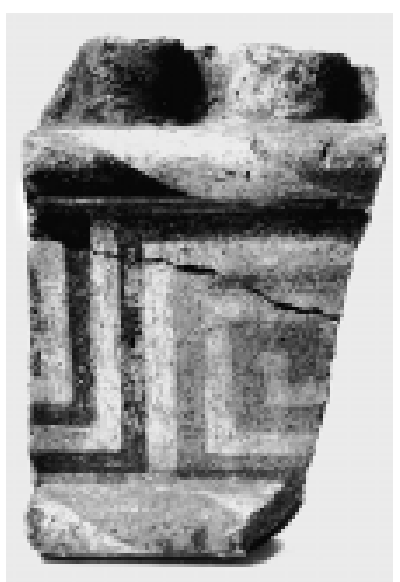

5. kép. Épületdíszító terrakottalap töredéke, a Wittgenstein-gyújteményből. Budapest, Szépmúvészeti Múzeum (múzeumi fotó)

fekete-polychrom csoport ritka feketemázas típusának egy példánya, amely valamikor a 7. század közepe és a 6. század közepe között készülhetett. ${ }^{35}$ Különösen figyelemre méltó a feliraton látható rho nemtipikus írásmódjának összehasonlítása a Valenza Mele által publikált egyik feliraton látható formájával (6-7. kép). ${ }^{36}$

Minthogy a Minervinitől leírt vagy cikkében illusztrált tárgyak, amennyiben egyáltalán azonosíthatók, szinte kivétel nélkül a Bonn, Brüsszel és Budapest által megszerzett anyagban vannak, ${ }^{37}$ feltehetô, hogy a Wittgenstein-gyújtemény archaikus kori leleteinek legalábbis túlnyomó többségét ez a három múzeum ôrzi. Mai ismereteink szerint máshol nem volt számottevő koncentrációja a „fondo Valentino”-n előkerült anyagnak, ${ }^{38}$ úgyhogy kiindulási pontként egyelőre a három gyújtemény tárgyainak a jelenlegi megoszlástól független, együttes elemzése kínál lehetőséget arra, hogy a Héra-szentély korai fogadalmi anyagának összetételét közelebbról megismerjük. Aláhúzza ennek a feladatnak a fontosságát a szentély most már bizonyítottnak tekinthető lokalizálása.

${ }^{35}$ R. J. Hopper, in: Perachora II (ed. T. J. Dunbabin-M. Robertson). Oxford 1962. 222-223, utalva a keltezés nehézségére. Egy új példány 2000-ben múkereskedelemben bukkant föl (Mele Gallery, Westport, USA, kiállítva: Cultura, Basel 2000, okt.).

${ }^{36}$ RIA, i. h. (fent 32. j.), 15, fig. 10, alulról a második.

${ }_{37} \mathrm{Az}$ illusztráció nélkül említett kora-korinthosi alabastron két kakas közt kígyóval a Szépmúvészeti Múzeumban van (ltsz. 50.204; közöletlen).

${ }^{38}$ Mindenesetre idetartozik a Wittgenstein-gyújteményből Drezdába került két korinthosi pyxis (ltsz. 106 és 107; egyelőre mindkettő közöletlen). Mintegy 60 Cumaeból származó korinthosi vázatöredéket C. W. Scheurleer londoni múkereskedelemból szerzett 1923-ban, és az ő gyújteményével kerültek 1934-ben az amsterdami Allard Pierson Museumba, de származásukra nincs további adat (Neeft, i. h. [fent 4. j.] 373, 13. j.); elképzelhető, hogy ha alkalom nyílik összevetésükre a három említett gyújtemény anyagával, egy vagy több összeillő töredék azt fogja bizonyítani, hogy szintén a Minervini-ásatásból valók. 


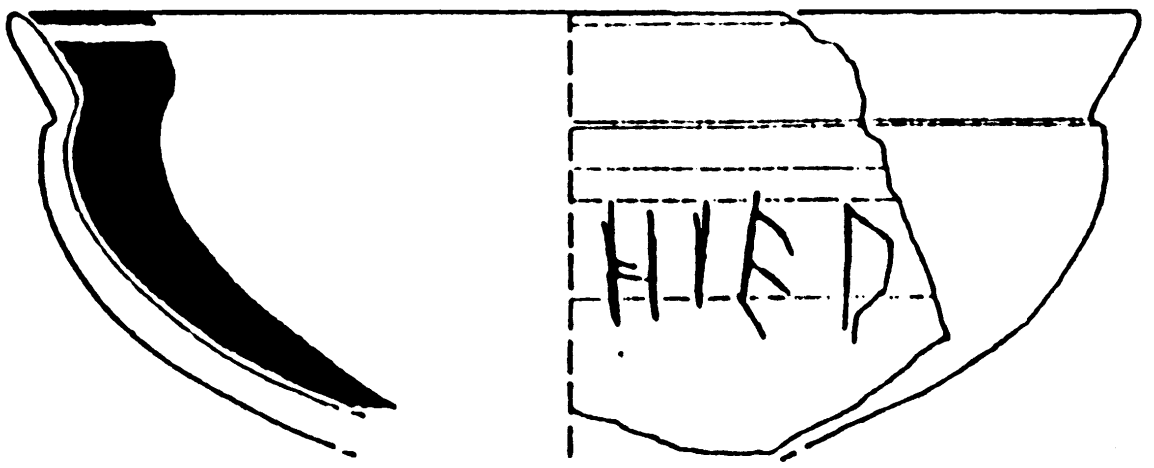

6. kép. Vázatöredék fogadalmi felirattal Cumaeból. Nápoly, Museo Archeologico Nazionale (RIA 3. ser. 14—15, 1991—92, 15, 10. kép)

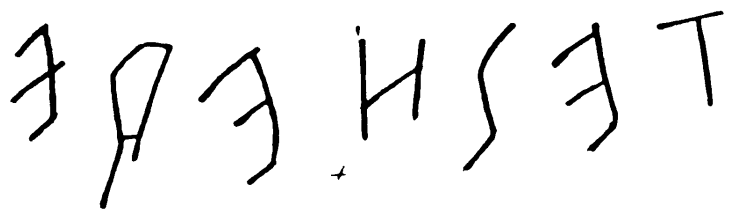

7. kép. Dedikációs felirat Hérának korinthosi vázáról. (BullArchNap N. S. 8, 1860, tav. 5)

Az utóbbi évtizedekben fóként az ókori Itáliával foglalkozó kutatás mind nagyobb figyelmet fordított az antik szentélyek típusok szerinti elkülönítésére és az egyes típusok egyedi funkcióinak meghatározására. ${ }^{39}$ A városokban és a hozzájuk tartozó temetókben találhatóktól ebben a tekintetben lényegesen különböznek a városon kívüli, extraurbánus szentélyek. Ezek között a nagyobb közösségek egymás közti érintkezésének színhelyéül szolgáló határszentélyek és a decentralizált kis települések kultikus, politikai és gazdasági központjának szerepét betöltő „vidéki”, tájban elhelyezkedő szentélyek mellett külön csoportot jelentenek a városi központok

${ }^{39}$ Néhány fontosabb munka az utóbbi évtizedekből: G. Pugliese Carratelli: PP 17 (1962) 241-246; G. Vallet, in: Atti Taranto 1967 (1970) 84-88 (a szuburbánus szentélyekról); J. de La Genière, in: Crossroads of the Mediterranean (ed. T. Hackens-N. D. és R. Ross Holloway). Louvain-Providence (Rhode Island) 1983. 163-189; F. de Polignac: La naissance de la cité grecque. Paris 1984; Santuari d'Etruria (a cura di G. Colonna). Milano 1985; I. E. M. Edlund: The Gods and the Place. Stockholm 1987 (ehhez M. Torelli: Latomus 49 [1990] 713-716); legutóbb R. Leone: Luoghi di culto extraurbani d'età arcaica in Magna Grecia. Firenze 1998. 31-35 (a fogalomról, gazdag irodalommal) és 45-46 a „fondo Valentino” szentélyéről (nem minden tekintetben pontos adatokkal); G. Greco, in: La colonisation grecque en Méditeranée Occidentale (Actes de la rencontre Rome-Naples 1995). Rome 1999. 231-233 (az értelmezések áttekintése). 


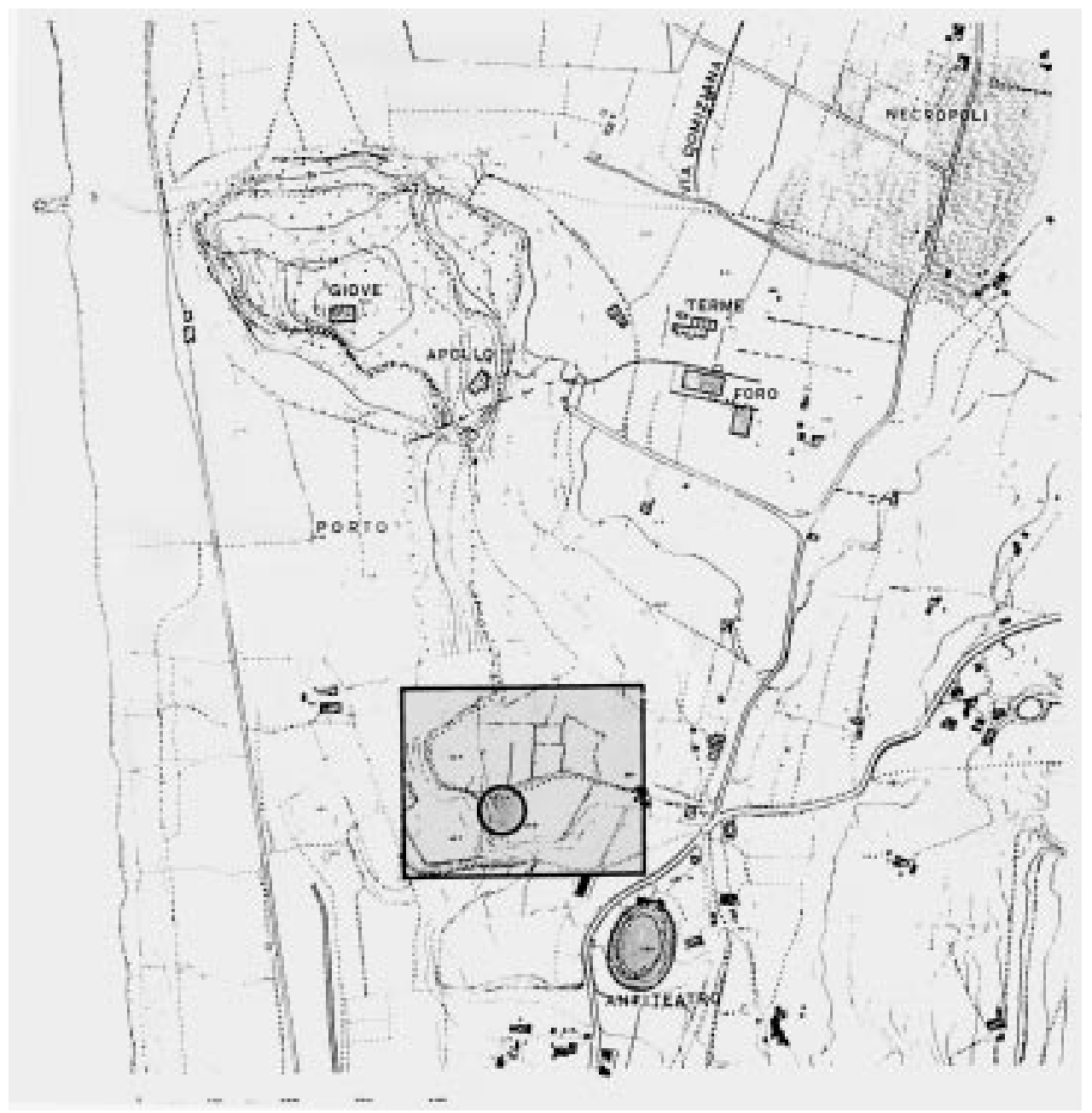

8. kép. Az ókori Cumae alaprajza a legfontosabb épületekkel. Fönt, északon az Akropolis dombja, tetején Zeus, délkeleti lejtôjén Apollón templomával. Lent, délen a téglalapba zárt terület az egykori „,fondo Valentino", benne a kör a pontozott vonallal jelzett városfaltól délre a Héra-szentély feltételezett helye; az Akropolis és a „fondo Valentino” közt nyugaton a kikötő (Studi sulla Campania preromana, 1995, tav. 17)

közvetlen közelében, de a városfalon kívül létesült szuburbáns szentélyek különféle típusai, amelyeknek közös sajátossága, hogy elhelyezésük folytán látogatóik elkerülhették a város hatóságainak ellenőrzését, beavatkozását, esetleg adókivetését, és szabadon érintkezhettek bárhonnan érkezett jövevényekkel. A „fondo Valentino” szentélye kétségtelenül az utóbbi típushoz tartozik, ahogy elhelyezése is szembetúnő- 
en mutatja (8. kép). Funkcióját azonban nemcsak a városfalon kívüli fekvése határozta meg, hanem talán még inkább a kikötőhöz való közelsége, ami más hasonló elhelyezésú társaival együtt különösen alkalmassá tette a távolabbról, vagy legalábbis hajóval érkezők fogadására. Erre utal a túlnyomó többségében Görögországból importált kerámiát tartalmazó fogadalmi anyaga, és ennek szem előtt tartásával az itt talált etruszko-korinthosi kerámiának is inkább a partmenti hajózás során tengeri, mint az egyelôre ebből a korból alig ismert szárazföldi, Latiumon át vezető úton való érkezése látszik valószínúnek.

Valenza Mele munkáiban részletesen foglalkozott a fenti adatok vallástörténeti jelentôségével. Az újabb kutatásokban amúgy is mind nagyobb figyelemmel tárgyalt Héra-kultusznak ${ }^{40}$ itt két aspektusa kap különleges hangsúlyt: új településre

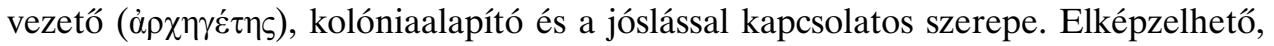
hogy az utóbbiban Apollón elődje volt Cumaeban. ${ }^{41}$ Az ásatások folytatása és a „fondo Valentino” szétszóródott anyagának részletes feldolgozása tovább árnyalhatja, megerôsítheti vagy cáfolhatja a jelenleg valószínúsíthető következtetéseket, és feleletet adhat arra a kérdésre is, vajon egyetlen Héra-szentély és abban egyetlen stips votiva volt-e az archaikus Cumaeban. ${ }^{42}$

${ }^{40}$ Elég itt az 1993-as Lille-i kollokvium anyagára utalni: Héra. Images, espaces, cultes (prés. J. de La Genière). Naples 1997.

${ }^{41}$ Valenza Mele: RIA, i. m. (fent 32. j.). L. ehhez legutóbb G. Camassa, in: Atti Taranto 1999 (2000) 331-343. Héra orakuláris szerepéról legutóbb szélesebb körben D. Novaro-Lefèvre: REG 113 (2000) $56-59$.

42 A problémához La Rocca-Rescigno-Soricelli: i. m. (fent 33. j.), 53-54 és 13-17. j; G. Greco: i. m. (fent 39. j.) 233, a Héra-kultuszban különösen gyakori kettôsségrôl városon belüli és kívüli szentély közt, az utóbbinak túlzott jelentőséget tulajdonítva a beavatási rítusban.

PS. A 17-18. lapon említett Foglia-gyúiteményrõl és egykori tulajdonosáról 2001-ben Nolában semmiféle értesülést nem sikerült szereznem. Valószínú azonban, hogy a név nem Toglia (így Knoll), hanem Foglia; egy ilyen nevú gyújtőtől származó őskori tárgyakat ôriz a salernói Museo Provinciale. 